Palestine, he never became the proverbial "professional" war veteran and military expert. He used to say jokingly, "Wherever I arrived, the front collapsed immediately."

Dr. Feilchenfeld completed his studies at Berlin, where he obtained his J.U.D. as well as the legal offices of assessor and referendar. Disturbed by trends in German society, he moved to England and finally to the United States, where he became a citizen in 1936.

At Harvard Law School, Professor Feilchenfeld became a leading figure in a new field which he did much to establish, namely: international economic law. During World War II, he went to the Treasury Department where he worked for what he insisted upon calling the Board of Economic "Illfare." By 1944 Dr. Feilchenfeld came to Georgetown where, at last, his wanderings ceased. His reputation rested upon his many publications in the field of international law.

Dr. Feilchenfeld will be missed by many eminent statesmen, scholars, and public servants who enjoyed his friendship and advice for so many years. Surely the Cosmos Club in Washington, D. C. will be different without him. But his greatest contribution lay in the inspiration and guidance which he lavished upon his students. It was moving but hardly surprising to listen to the many students who came to pay their last respects to Dr. Feilchenfeld. They all said substantially the same thing: "He had a great influence on my life; he was like a father to me." Surely these devoted students are his greatest legacy.WiLliam V. O'BrieN

\title{
SPECIAL ANNOUNCEMENTS
}

\section{REPORT OF NOMINATING COMMITTEE}

At the annual meeting of The American Political Science Association, to be held September 6-8, 1956 in Washington, D.C., the Committee on Nominations will propose the following officers for 1956-57: President-Elect, V. O. Key (Harvard University); Vice-Presidents, Carl Brent Swisher (Johns Hopkins University), Wilfred Binkley (Ohio Northern University), Albert Lepawsky (University of California, Berkeley); Secretary, Gladys Kammerer (University of Kentucky); Treasurer, Max Kampelman (Washington, D.C.); Members of the Council for two years, William T. R. Fox (Columbia University), Ruth Weintraub (Hunter College), John D. Lewis (Oberlin College), Thomas Eliot (Washington University, St. Louis), Alexander Heard (University of North Carolina), York Willbern (University of Alabama), Allan Saunders (University of Hawaii), Christian Larsen (Sacramento State College). 